\title{
Exploration on Reform Model for College Ideological and Political Education under the Field of Vision of $\mathrm{Xi}$ Jinping's Political Educational Concept
}

\author{
Dayang Wang1, Qiuting Lu$^{2}$ \\ ${ }^{1}$ Student Bureau of Jilin JianZhu University, Changchun, Jilin, China \\ ${ }^{2}$ Student Bureau of Jilin Agriculture University, Changchun, Jilin, China
}

\begin{abstract}
Today, the college ideological and political education has a wide influence nationwide, especially in General Secretary Xi Jinping's political educational concept, the effect of ideology as a guide to action becomes more and more obvious. In order to promote further development of college ideological and political education, colleges and universities should move forward along the road combining the theory and the practice with social development as the opportunity to master the big direction. The college ideological and political educators are required to possess advanced teaching concepts and serve as the guider of undergraduates during their growth.
\end{abstract}

Keywords: political educational concept; college ideological and political education; reform

\section{Background}

\subsection{Objective of the study}

On September 18, 2017, China held the 19th National Congress of Communist Party, and on the Congress, General Secretary Xi Jinping made important lectures to the people with the core contents as following: "Never forget why you started ". The holding of the 19th National Congress brings the great reform to the ideological world of Chinese people. During the development of Chinese society, General Secretary Xi Jinping's important ideology brings us a guide to action for our life, especially General Secretary Xi Jinping's political educational concept brings a glimmer of hope to the development of college ideological and political education in China. The objective of the study is to bring forward the exploration on the reform model for college political education through in-depth study on General Secretary Xi Jinping's political educational concept and by combining the issues existing among the ideological and political education in China at present.

\subsection{Significance of the study}

Through the study, General Secretary Xi Jinping's political educational concept and today's college ideological and political education may be combined to offer a new angle of view for the development of college ideological and political education, and brings the exploration on some theory and practice, and through the combination of General Secretary $\mathrm{Xi}$ Jinping's essence of thought and college ideological and political education, promote the overall development of college ideological and political education. 


\section{Xi Jinping's Ideological and Political Educational Concept}

The lecture by General Secretary Xi Jinping definitely pointed out that, in order to realize the great renaissance of Chinese nation, the cadres of the CPC central committee are required to keep advancement and bring forward the great thought of strengthening party self-discipline in all directions. The thought of General Secretary Xi definitely presents the importance of ideological and political education, for a person's thought will directly influence the behaviors, and therefore, only the awareness in thought is higher, may the person's behaviors in details comply with the people's will, the requirements of the communist party and the nation, and may accordingly contribute to the realization of the Chinese Dream. (Zhang and Ma, 2017)

\subsection{Fundamental orientation}

First, greeting the challenge without avoiding the conflicts in ideological and political education. Since the founding of Chinese Communist Party, China has experienced the victory of new-democratic revolution, the great victory against imperialism aggression, and at the great blood-shed age, it's the Chinese Communist Party who lead the Chinese people to get rid of the situation of being lagged behind and vulnerable to attacks, and the poor starving and finally be ushered in today's happy life. (Gao and Huang, 2013) We may say, "No Communist Party, No New China", saying nothing of today's fortune in China. Chinese Communist Party has been 60 years old, and during the hard time, many members of communist party sacrificed their lives for the people's interests, and however, there're also some members fail to deeply recognize the noble quality a party member should possess in the sugar-coated shell, being corrupted continuously in the life, and therefore, they not only loss their political career, but also bring serious negative impact on Chinese people. Facing this situation, General Secretary brings forward the concept, i.e. face up to the issues existing among the members of communist party, needn't avoid any conflict, correctly regard the issues, and starting from the angle of ideological and political education, timely correct the ideological concept of Chinese youth, prevent the youth from walking on crooked road and the influence of crooked road on their own overall development. (Zhang, 2016)

Secondly, ideological and political education may not deviate from the navigation mark. Today, after the continuous efforts of the people of all nationalities of the country, our material standard of living and spiritual standard of living are improved in all round, and however, the increasingly-increased demands of the people on material culture may not be met, especially in today with abundant material life, people's demands on spiritual life has also been continuously improved, however, the country fail to meet their improved demands by now. (Guo and Lu, 2014) In order to realize the dream of great renaissance of Chinese nation, General Secretary Xi Jinping brings forward the great conception of "Chinese Dream", the purpose of which is to continuously improve the Chinese people's standard of living, realize the establishment of overall well-off of the country, and within the country, completely promote the modernization construction. However, the premise of realizing these great conception is the thoughts of Chinese people, only if all people of the country work together, the great conception of Chinese Dream may be smoothly realized, and the people's life may become happier, and accordingly, the country may maintain prolonged stability. (Li and He, 2014)

\subsection{Major content}

The content of Xi Jinping's ideological and political education is wide, involving various fields in China, creating a good environment for the establishment of ideological and political education system in China, and plays a great function on the completion of ideological and political education system.

The first is the ideological concept education of "Three Confidences". (Mao H, 2014) General Secretary Xi Jinping once said, "ideal and faith" are the "calcium" of Chinese people, and if there's no "ideal and faith", Chinese people will suffer from "chondropathy ", and will lose confidence during the development of China in future. It may be seen that "idea 
and faith" are important to the development of China in future. During the future development road of China, some puzzles shall inevitably appear due to some objective reasons, and however, in order to make Chinese people strengthen their own cultural power and accordingly apply their ideal and faith into their daily life when facing the huge pressure and challenges, and accordingly possess more support in faith and finally realize Chinese 's dream of great renaissance. (Ma and Guo, 2013)

The second is the education in law and discipline. With the continuous development of Chinese society, the people's ideological idea changes a lot, especially since the reform and opening-up, under the powerful promotion of economic globalization, Chinese economy has acquired overall development and prosperous, and Chinese people's standard of living is also improved. (Cui and Liu, 2015) However, some disadvantageous influence on social development also come into the people's life. Many Chinese officers utilize their powers of office to continuously participate in bribery and bribe-taking under the driving of interest, although their personal economic capability is improved continuously, however, their behaviors bring adverse impact on other social members. This kind of corruption behaviors are not only unfavorable to their own personal development, but also cause very disadvantageous impact on the social environment of China, and the influence of these greedy officials greatly challenges the social equity.

The last is education in patriotism with traditional culture as the carrier. China is a big country with a civilization history of five thousand years, and in today when Chinese civilization is long standing, why Chinese culture isn't interrupted after years of baptism in the historical river, it's determined by the advancement of Chinese culture from some angle of view. In today when Chinese society's development is convenient, the network and digital media is widely applied, some junk novels run into people's life, especially the youth's eyes. These junk culture will generate adverse influence on these youth, and therefore, such junk culture should be eradicated by strengthening the upgrading of people's ideological concept and changing the people's original life style. With excellent traditional Chinese culture as the carrier, carry out the corresponding patriotism education on Chinese youth, help the them set up correct ideological concept, improve their ideological quality, and accordingly improve their moral cultivation in all round, so as to contribute greatly to the social progress. (Lin and Rong, 2016)

\subsection{Characteristics}

Firstly, simple words, easily comprehended by the people. Many ideology and politics of General Secretary Xi Jinping apply straightaway language to transfer the positive energy to the people, and language, as a cultural symbol, plays important role in the daily life of Chinese people. Language is not only a tool for communication, but also a tool for people to understand the culture; in addition, thanks to the charm of language, language may exert the huge promotion function during the formation of people's ideological field, and influence the people's detailed behaviors in life. In General Secretary Xi Jinping's important lecture, straightaway languages are mostly applied to present the thoughts in the form of words General Secretary Xi Jinping wanted to express. Wherein, many famous judgment features amiable language in a favorable form. (Niu, 2015)

Secondly, literary quotation applied to boost layer upon layer. During the social development, a lot of practices appear. The continuous progress of the society urges us to follow up the social step, and carries out the reform and integration of personal ideological concept continuously, making our own behaviors suitable to the social mainstream culture. Many reports of General Secretary Xi Jinping's have cited some classic stories in Chinese traditional culture, through which reflect some social facts and explain simple truth, making the people master the essence of some Chinese traditional cultural knowledge and combine the reasonable connotation of traditional culture with our own actual life, so as to continuously complete our own culture through continuous self-examination. This is the important function for General 
Secretary to apply the literary quotation, meanwhile, each story taught by General Secretary is targeted; General Secretary continuously concludes the experience and lessons, changes the ideology continuously, and finally forms the great conception of Chinese Dream according to the overall trend of today's social development and some social issues frequently appeared in today's society. General Secretary's each words are determined according to the national conditions of China, featuring great meaning, and may generate great influence on the people's life, worthy of profound thinking by each Chinese.

\section{Shortage of Traditional College Ideological and Political Education}

3.1Absence of principal status of the students

College ideological and political education is always is a highly anticipated major, for ideological and political education concerns the modeling and growth of personality and plays a great role in the development in future society. However, from the development trend of ideological and political education specialty at present, students have a poor expression at classroom, forming the lack of consciousness of subject in class, which is unfavorable to the further study in ideological and political education in future. In traditional classroom teaching, teachers are the subject of classroom, and students could only listen to the teachers without any chance to make a statement or conduct in-depth discussion with teachers with regard to relevant knowledge, therefore, under such study circumstance, many students' learning incentive is poor, and their learning enthusiasm may not be completely exerted. Especially the classroom teaching mode features less interaction between students and teachers, which hinders the development of college ideological and political education specialty, and is unfavorable to the absorption and understanding of relevant knowledge.

3.2Single teaching mode

In traditional exam-oriented education mechanism, score is everything, and score is the only standard for measuring the students' study level, due to which reason, in order to acquire a high score, many students carefully listen to the teachers at class and carefully record the content teachers taught at class, and close to the final exam, they would crazily recite the topics and contents, aiming at acquiring a satisfying score during the exam, and this kind of teaching mode is the so-called "spoon-feeding" teaching mode. (Shi and Xiao, 2016) In such "bookworm" style teaching mode, many students are seriously lack of learning incentive, the phenomenon of unwilling to learn and not to learn is common. The students fostered through such kind of teaching mode are only kind of repeater-style talents, who don't skillfully master the theoretical fundamental knowledge during some ideological and political education, and therefore, they may not combine the theoretical application with practice to ignite their personal academic inspiration, and accordingly fail to provide theoretical guidance for their development in future. (Tang, 2017)

\subsection{Weak educational effectiveness}

For a long time, when undergraduates accept the ideal and belief education, patriotism education, national spirit education and citizen moral education, the ideological concept of these ideological and political education in colleges and universities only rests on the theoretical level, and in the students' eyes, these are only some empty talk without practical efficacy, therefore, relatively speaking, the practical effects of these theories are not obvious, lack of the effective means and methods for combining the theory and the practice. For the undergraduates majored in ideological and political education in colleges and universities, empty talk has not much effect, and may not bring important influence on the life. In order to overcome the malpractices in the education, it requires to combine the ideology of the education with humanistic spirits advocated by the society today, so as to promote the practicability of college ideological and political education.

(Guo and Ma, 2014) 


\section{Promoting the Exploration on Reform Model for College Ideological and Political Education}

4.1Creating good ideological and political education environment

Under the influence of General Secretary Xi Jinping, we should pay more attention to the development of college ideological and political education, and in order to improve the ideological and political education level for undergraduates, we firstly should create the good ideological and political education environment. (Shi, 2016) With regard to teaching methods, we should lay emphasis on the principle of teaching students according to their aptitude, provide special educational guidance for the students according to their own learning characteristics and study status, and organically combine the excellent traditional cultural essence of Chinese civilization and relevant political principles in ideological and political education, so as to encourage the students to learn the great essence of Chinese culture during the understanding of ideological and political education theory, and combine the theory with their own study and growth life to guide their practical awareness. Besides, it also requires to create good ideological and political education atmosphere, i.e. not only strengthen the construction of material standard of living, but also improve the influence of spiritual culture construction on the undergraduates; finally, it requires to combine the construction of campus culture and undergraduates' ideological and political education, so as to create a simple, hardworking and modest learning atmosphere, enriching the teaching connotation of ideological and political education.

4.2Improving the accomplishment of college educators

Why college ideological and political education has so many problems, the reasons involve the students and the colleges and universities as well, i.e. the students' learning attitudes are not good, the leaders of colleges and universities pay less attention to college ideological and political education, and however, the more important reason is related to the teachers dedicating to college ideological and political education, as the most important circle in practical teaching work, as long as the teachers' theory and cultural level reach a new height, may the students be benefit from the education. (Tang and Rong, 2015) Therefore, during the further work of ideological and political education, it requires to strengthen the construction of professional teaching staff dedicating to ideological and political education, improving their teaching quality and teaching level and help the teachers dedicating to ideological and political education specialty build correct working concept, i.e. with the students' study as the highest working target and with the output of more professional knowledge talents to the society as the target, so as to contribute to the social progress and exert their ideological guiding function as human soul engineers.

\section{Conclusions}

In conclusion, we should, in accordance with General Secretary Xi's political educational concept, carry out necessary improvement against the teaching mode of college ideological and political education in China and improve the capability and level of college ideological and political education, so as to guide the students' ideology, offer the students correct cognition and help them settle the practical puzzles and conflicts, and accordingly promote the healthy development of undergraduates.

\section{Conflicts of Interest}

The author declares no conflicts of interest regarding the publication of this paper.

\section{Acknowledgment}

The phased research result of Jilin Province Education Science "13th Five-Year Plan" General Planning Project "Innovative Research on Ideological and Political Work in Colleges and Universities - Research on the Educational Path of College Students' Socialist Core Values in the New Media Environment" (Project Approval Number: GH180409); The phased research result of the "13th Five-Year" Social Science Project of the Jilin Provincial Department of Education 
"Research on the Targeted Effectiveness of the "Learning and Dreaming of College Students" (Contract No.: JJKH20190899SZ).

\section{References}

[1] Cui T.T. and Liu S.B. (2015). An Exploration of Practical English Teaching for Graduate Students based on New Media Support. Chinese Electrification Education, (06), 122-126.

[2] Gao H.H. and R.H. (2013). The Reform Strategy of University Thought Politics Education Reform. Journal of Anhui Institute of Science and Technology, 31(01), 123-125.

[3] Guo H.Y. and Lu Z.L. (2014). Research on the Reform and Innovation of University Thought Politics Education under the New Media Vision. Jilin Agricultural University.

[4] Guo Z.Y. and Ma H.H. (2014). Reform of University Ideology and Politics under the Change of Media Environment. Jiangsu High Education, (02), 118-119.

[5] Li D.J. and He Z.D. (2014). Research on the Reform Strategy of the Ideological and Political Education Reform in Universities. $B B S,(02), 30-32$.

[6] Lin R. and Rong M.M. (2016). Research on the Reform of University Thought Politics Education. Journal of Wenzhou University (Natural Science Edition), 32(03), 50-53.

[7] Ma J.F. and Guo J. (2013). Research on the Countermeasures of University Ideological and Political Education Reform. Journal of Chongqing Technology and Industry University (Social Science Edition), 30(04), $148-152$.

[8] Mao H. (2014). Methods of Reform and Innovation in the Reform and Innovation of University Thought Politics in the New Era. Journal of Chi Feng College (Natural Science Edition), 30(02), 262-263.

[9] Niu Y.N. (2015). A Review of the Research on the Reform of University Thought Politics Education. New Curriculum (Teaching Research), (04), 88.

[10] Shi M. (2016). A Review of the Research on the Reform of Ideological and Political Education in Universities. Journal of Hunan Institute of Science and Technology, 30(10), 107-108.

[11] Shi M. and Xiao Y.Z. (2016). A Review of the Research on the Reform of Ideological and Political Education in Universities. Journal of Hunan Institute of Science and Technology, 30(10), 107-108.

[12] Tang X. (2017). Reflections on the Reform of the Ideological and Political Education in Contemporary Universities. Journal of Beijing Institute of Electronic Science and Technology, (03), 38-42.

[13] Tang X.S. and Rong Y.(2015). Reflections on the Reform of the Ideological and Political Education in Contemporary Universities. Journal of Beijing Institute of Electronic Science and Technology, (03), 38-42.

[14] Zhang J.H. (2016). The Strategy of the Reform and Innovation of Education Reform in University Ideology under the New Situation. High Education Journal, (16), 241-242.

[15] Zhang R. and Ma H.Y. (2017). The Ideological and Political Education under the Concept of Green Development Horizon Research. Modern Communication, 08(03). 